\section{畳上での防振ゴムを利用した環 境振動測定方法の検討}

\section{EXAMINATION OF ENVIRONMENTAL VIBRATION MEASUREMENT USING VIBRATION CONTROL RUBBER ON TATAMI}

冨田隆太- $* 1$ 後藤佑太 -2

青木怜依奈—— $* 3$

キーワード

振動伝達率，防振ゴム，畳，設置共振

Keywords:

Vibration transmission rate, Vibration control rubber, Tatami, Mounted resonance

$\begin{array}{lll}\text { Ryuta TOMITA } & * 1 & \text { Yuta GOTO } \\ \text { Reina AOKI } & * 3\end{array}$

We have proposed a method for estimating the vibration acceleration level of the floor structure with high accuracy by preventing the mounted resonance of the carpet floor. In this paper, using the method proposed in this study, we conducted an experimental study on thick tatami, unlike carpets. As a result, it was suggested that when a tatami with polystyrene foam as the core material, which is generally and commonly used, is installed on the concrete slab, the mounted resonance is prevented and the vibration acceleration of the concrete slab is accurately calculated.
1.はじめに

建築物内の環境振動測定には, 圧電型加速度ピックアップに振動 計を組み合わせたものや振動レベル計等が用いられることが多い ${ }^{11}$ いずれも振動ピックアップを床に設置する際には, 「設置共振」に留 意する必要がある。既報 ${ }^{2}$ ， 3)で述べたように，環境振動測定に関す るマニュアル等例えば4)でも，「床上にタイルカーペットやじゅうたん などの柔らかい表面仕上材が施工されている場合には，可能な限り 仕上材を取り除き躯体上に設置する」と記載されている。

また, 日本建築学会の環境振動測定分析小委員会が 2012 年に実施 した測定経験者へのアンケート ${ }^{5}$ によると，環境振動測定において 悩屯項目として, 「測定位置・点数」に次いで,「測定機器の設置方法」 が多く挙げられており，アンケート対象者 (環境振動測定・分析を行 っている技術者)の過半数の指摘があった。また, 『瞫やカーペット の場合，測定できないケースが多い』等の記述が見られていること から，環境振動測定を行う上で早急に解決す心゙き問題と位置付けら れる。

そこで，筆者らは，カーペット床を対象としてこれまで設置共振 を防ぐ方法について実験的検討を行ってきている。設置共振を防ぐ 場合には，一般的には，共振周波数を高い周波数にシフトするよう な検討がこれまでも行われてきている。例えば，最近の研究結果と

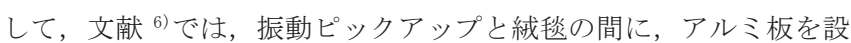
置して, 設置共振周波数を高くする方法が検討されている。 $\sqrt{2}$ 倍程 度共振周波数が高周波数にシフトしているが，共振周波数が $50 \mathrm{~Hz}$ 程度の絨毯では, $70 \mathrm{~Hz}$ 程度に共振周波数がシフトしており, $80 \mathrm{~Hz}$ 程度までの測定を考慮すれば，まだ課題がある。

我々が提案している方法は, 文献 $\left.{ }^{21}, 3\right)$ のうに, 柔らかい防振ゴ
ムを利用して, 逆に低い周波数で防振ゴムと振動ピックアップによ る設置共振を発生させ, その振動伝達率を利用寸ることで, カーペ ット床を剥がさずに，カーペット床下部の床構造の振動を正確に測 定しようとする方法である。文献 ${ }^{22,3)}$ の結果, 本研究の提案方法は 鉛直振動, 水平振動共に, 有用な 1 つの提案方法になると示唆され た。さらに，文献 ${ }^{7)}$ では，コンクリートスラブより，かなりインピ ーダンスレベルが小さい木造床を対象として，鉛直振動に関する検 討を行い, 本研究の提案方法の妥当性を報告した。また, 文献 7)で は, 防振ゴム単体の振動伝達率の測定を, コンクリートスラブ $300 \mathrm{~mm}$ と木造床で行ったが，振動伝達率が小さくなる高周波数でも同様の 傾向を示しており, 現在の振動測定機器を用いれば, S/N の問題は 小さいと考えられる。

そこで，本報では，これまでの研究で行ってきた知見を利用し， カーペットに比べて, 厚さのある畳床を対象として実験的検討を行 った結果を報告する。なお，本報告の対象範囲は，鉛直振動による 現場での畳床の実験を対象とし, 水平振動に関する検討は今後の課 題とする。また, 本研究のようなアプローチにより, 設置共振を防 ぐような研究は, 筆者らが報告した文献 ${ }^{2), 3)}$ 以外には, 見当たらな い。

\section{2. 防振ゴムを利用した測定方法の概要}

本研究の提案する振動測定方法は, 設置共振している周波数範囲 について, 単振動系の振動伝達率を利用して, 床構造そのものの振 動加速度レベルを推定する方法である ${ }^{2), 3)}$ 。振動伝達率の計算式は,

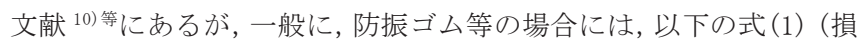
失係数一定型の抵抗を仮定) で求められる。

本稿は 2019 年日本騷音制御工学会秋季研究発表会 ${ }^{8)}, 2020$ 年日本騒音制御工学会春季研究発表会 $\left.{ }^{9}\right)^{(2}$ に加えて分析を行い, 加筆及び再構成したものである。

日本大学理工学部建築学科 教授・博士 (工学)

( (101-8308 千代田区神田駿河台 1-8-14)

Prof., Dept. of Architecture, College of Science and Technology, Nihon Univ.,

(侏竹中工務店（元日本大学大学院生） 修士（工学）

日本大学大学院理工学研究科建築学専攻 大学院生 Dr. Eng.

*2 Takenaka Corp., M. Eng.

${ }^{*} 3$ Grad. Student, Dept. of Architecture, Graduate School of Science and Technology, Nihon Univ. 


$$
\tau=\sqrt{\frac{1+\eta^{2}}{\left(1-\left(f / f_{n}\right)^{2}\right)^{2}+\eta^{2}}}
$$

ここで, $\eta$ : 損失係数, $\mathrm{f}$ : 加振周波数, $\mathrm{fn}$ : 固有周波数である。

図 1 に, 周波数比 $(\mathrm{f} / \mathrm{fn})$ と式(1) によって求められた振動伝達率 $\tau$ の特性を示寸。図を見ると, 周波数比が $\sqrt{2}$ 以上になると振動伝達率 が 1 (振動伝達レベルが 0dB) 以下となり, 損失係数による変化は小さ く, 振動伝達率は小さくなる。

本研究の提案は, 周波数比が $\sqrt{2}$ 以上の大きい周波数について, 設 置共振させたときの振動伝達レベルを減算して推定する方法である。 すなわち, 床仕上げ材上に, ば称定数の十分に小さい防振ゴムを載 せて測定を行うと, 周波数比が $\sqrt{2}$ 以上の周波数範囲で振動伝達率の 低下分によって振動加速度が小さくなる。それらから，レファレン スとして事前に測定した防振ゴム単体の值を減算することにより, 振動伝達率の低下分がキャンセルされる方法である。

従来の研究と大きく異なる点は, 柔らかい床仕上げ材の上に, 治 具として更にばね定数の小さい防振ゴムを設置し, 強制的に設置共 振を低域で発生させ, 図 1 の $\mathrm{f} / \mathrm{fn} \geqq \sqrt{2}$ の周波数領域と振動伝達レべ ルを利用し，床仕上げ材下の振動を推定することである。

\section{3. 畳床の設置共振特性}

実験は，鉄骨造，一部鉄骨鉄筋コンクリート造(地上 18 階，地下 3 階)の建物の 9 階で行った。振動レベル計 (RION,VI-55)の振動ピ ックアップ(PV-83C, 約 $335 \mathrm{~g}$ ) を対象として, 床上(コンクリートス ラブ $160 \mathrm{~mm}+$ ビニル床シート $2 \mathrm{~mm}$ ) に設置した。衝撃源には, 一定の衝 撃力特性を有するゴムボール (JIS A 1418-2 $2^{11)}$ の衝撃力特性 (2)) を用 いた。加振点から $1 \mathrm{~m}$ 離れたところに, 測定点を設けた。

対象とした畳は, 表 1 に示寸本畳及び建材畳の 2 種類とした。実 験は, 床上とその上に畳を施工したパターンで振動加速度波形を測 定した。その後, 時定数 $10 \mathrm{~ms}$ で分析を行い, 床上に対する畳上の相 対振動加速度レベルを求めた。図 2 に, その結果を畳の設置共振特 性として示寸。図を見ると，T1 は $20 \sim 25 \mathrm{~Hz}$ で共振が見られ，T2 は $50 \sim 63 \mathrm{~Hz}$ で共振が見られる。以上のように，畳上では床上と異なる 振動加速度レベルとなることが確認された。なお, 文献 2)で報告し たカーペットの設置共振特性は, 共振周波数のピークが $63 \sim 80 \mathrm{~Hz}$ 帯域で最大でも $10 \mathrm{~dB}$ 程度に対して, 睍は共振周波数のピークも低く, 共振の程度もかなり大きいことがわかる。

本報では, これまでカーペット床について検討してきた, 設置共 振を防ぎ, 床構造の振動加速度レベルを推定する方法について, 厚 さのある畳にも適用できるかについて実験的検討を行った。

\section{4. 畳床下のコンクリートスラブ素面の振動加速度レベルの推定}

\section{1 測定及び推定方法}

本研究では，文献 ${ }^{2)} て ゙$ 示したように，以下の手順で測定及び推定 を行うことを提案している。なお，測定条件は，3．で示した測定 と同様である。

「測定及び推定方法」

(1) 図 3 のパターンB(睤上)で測定を行う。

(2) 図 3，4のパターンC(畳十防振ゴム上)で測定を行う。

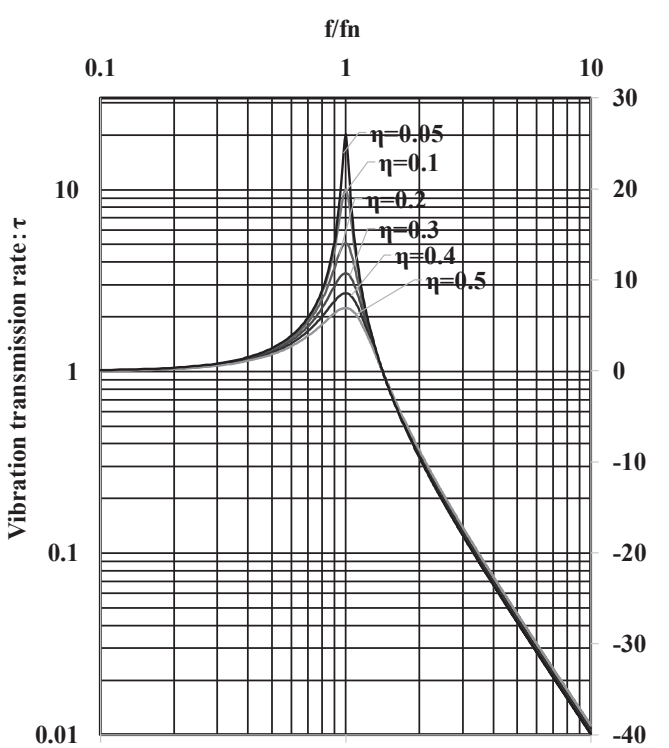

図 1 損失係数一定の振動伝達率

表 1 試験体概要

\begin{tabular}{|c|c|c|c|}
\hline No. & 厚さ(mm) & 断面構成 & 質量 \\
\hline T1 (本畳) & 55 & 畳表 $5 \mathrm{~mm}+$ 菒 $50 \mathrm{~mm}$ & $28.5 \mathrm{~kg}$ \\
\hline T2（建材畳） & 55 & $\begin{array}{c}\text { 畳表 } 5 \mathrm{~mm}+\text { インシュレーション } \\
\text { ボード } 15 \mathrm{~mm}+\text { 押し出し法ポリ } \\
\text { スチレンフォーム } 25 \mathrm{~mm}+\text { } \\
\text { シュレーションボード } 10 \mathrm{~mm}\end{array}$ & $13.0 \mathrm{~kg}$ \\
\hline
\end{tabular}

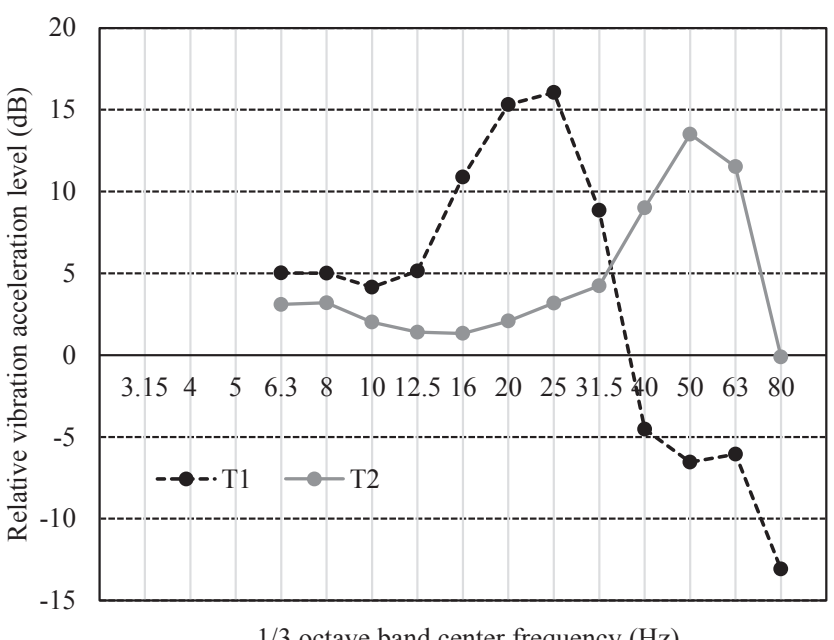

$1 / 3$ octave band center frequency $(\mathrm{Hz})$

図 2 畳の設置共振特性

Vibration control rubber

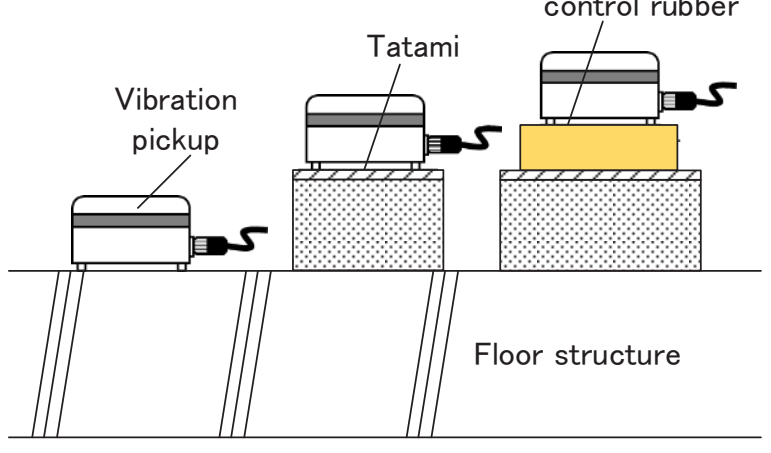

Pattern A

Pattern B

Pattern C

図 3 振動ピックアップの設置パターン 
(3) (2)-(1) (パターン Cーパターン B) を行い, 共振周波数 $(\mathrm{f} / \mathrm{fn}=1)$ と $\mathrm{f} / \mathrm{fn}=\sqrt{2}$ より高い周波数帯域を求める。

(4)防振ゴムの基本特性として, 図 5 の床+防振ゴムで測定した 結果より, $\mathrm{f} / \mathrm{fn}=\sqrt{2}$ より高い周波数帯域以降の相対振動加速 度レベルを(2)から減算する。

(5) (3)で, $\mathrm{f} / \mathrm{fn}=\sqrt{2}$ より低い周波数帯域については, パターン $\mathrm{B}$ の結果をそのまま用いる。

\section{2 測定結果及び推定結果}

図 6 に防振ゴム単体の相対加速度レベル差を示す。次に, 4.1 で 示した「測定及び推定方法」により，(1)(2)の測定を行い，(3)の結果 を図 7 に示す。図 7 を見ると, 建材畳 T2 の場合には, 図 6 と同様の $16 \mathrm{~Hz}$ 帯域が共振周波数であることが確認できる。 $\mathrm{f} / \mathrm{fn}=\sqrt{2}$ より高い 周波数帯域は, $25 \mathrm{~Hz}$ 帯域以上となる。一方, 本畳 T1 の場合には, 12. $5 \mathrm{~Hz}$ 帯域に共振周波数があり, $\mathrm{f} / \mathrm{fn}=\sqrt{2}$ より高い周波数帯域は, $20 \mathrm{~Hz}$ 帯域以上となる。4.1の(4), (5)の結果について, 図 8 に建材畕 T2 を推定した結果を, 畳を剥がした実測值と併せて示す。図を見る と, 設置共振がキャンセルされ, 畳を剥がさずに実測值を十分に推 定できていることがわかる。

図9に本畳T1を推定した結果を 示す。なお, T1 の場合には, 4.1 の(3)で $12.5 \mathrm{~Hz}$ 帯域に共振周波数 があったため, 防振ゴム単体の相 対振動加速度レベルを，1/3 オク ターブバンド中心周波数で 1 帯域 低域にシフトした。図を見ると， T1 (パターン B)の畳上そのままで 測定した結果に比べれば，畳を剥 がした実測值に若干近づいている が, 最大 $11 \mathrm{~dB}$ 程度の違いが見られ る。ここで, 図 7 の $\mathrm{T} 1$ を見ると， 共振の程度が防振ゴム単体に比べ て $3 \mathrm{~dB}$ 以上小さくなっている。そ こで, 文献 ${ }^{7)}$ の木造床上の場合に 適用した推定方法 2(4.1の(4)で全 周波数帯域を補正する)で, 再度推 定した結果を図 10 に示寸。図 10 を見ると，図 9 に比べてかなり実 測值に近い推定結果が $50 \mathrm{~Hz}$ 帯域 以外では得られ, 特に加速度の大 きい周波数帯域 $(20,25 \mathrm{~Hz})$ では $3 \mathrm{~dB}$ 以内の差となった。

\section{5. 畳床下の木造床素面の振動加 速度レベルの推定}

\section{1 実験概要}

実験は，木造戸建て住宅の 2 階 で行った。木造床と天井の仕様は, フローリング円 $12+$ 床暖房パネル (P) $12+$ 構造用合板( 15 , 空気層 275〈断熱材: G/W16K(7) 75>, 床根太

$38 \times 235 @ 455$, 吊天井根太 $38 \times 140 @ 455$, 天井 : 石膏ボード囚 $9.5+9.5$ +ビニールクロス貼であった。

3. と同様に, 振動レベル計の振動ピックアップを床上に設置し た。衝撃源には，3．と同様のゴムボールを用いた。測定点は室の 中央点とし, 加振点は対角に $1.7 \mathrm{~m}$ 離れた位置とした。対象とした畳 も，3.と同様の表 1 に示す 2 種類であった。

\section{2 測定結果及び推定結果}

4.1 と同様な推定方法で検討を行った。なお, 防振ゴム単体の基

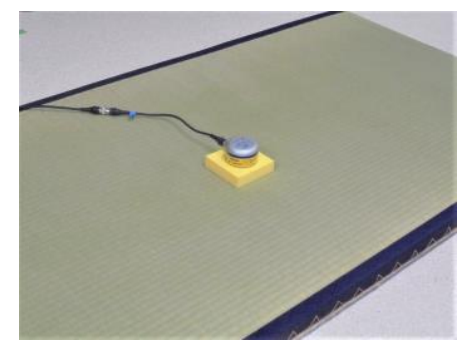

図 4 パターンCの測定

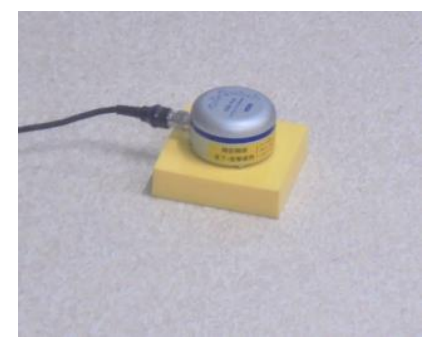

図 5 防振ゴム単体の測定

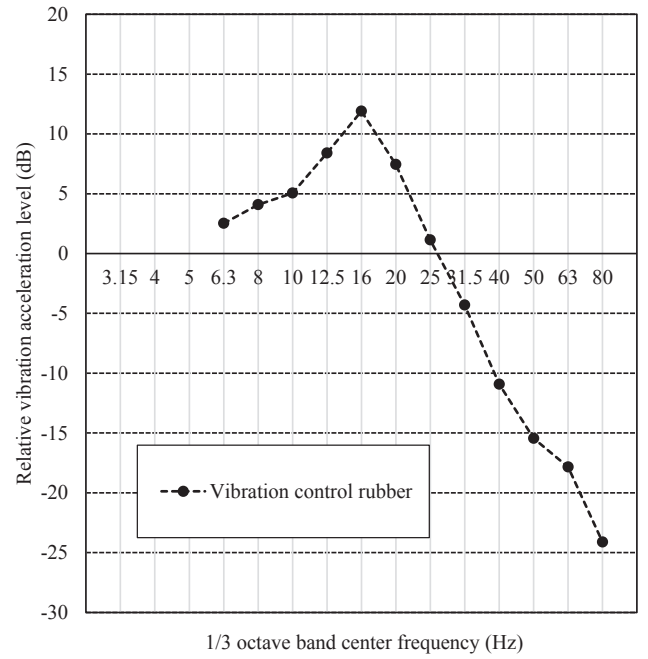

図 6 防振ゴム単体の測定結果

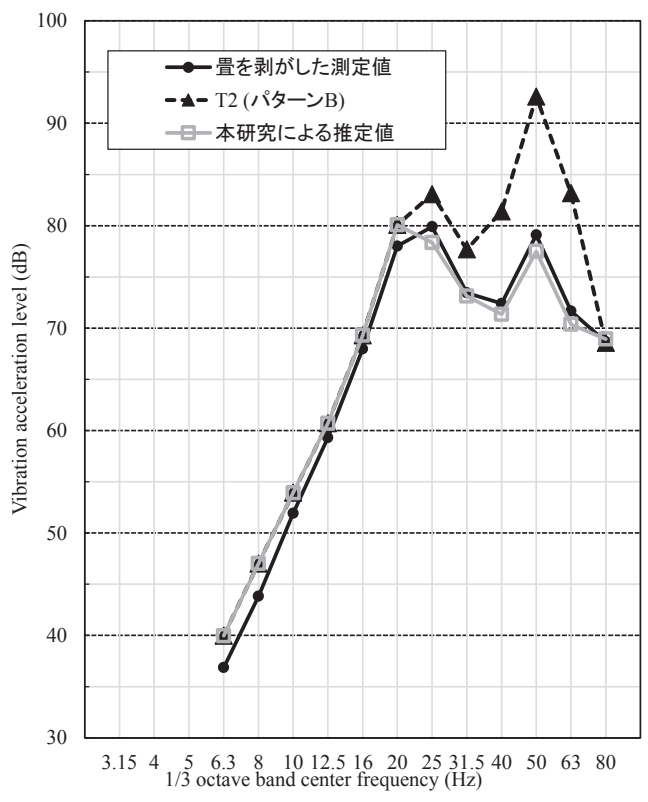

図 8 T2 の推定値と測定值

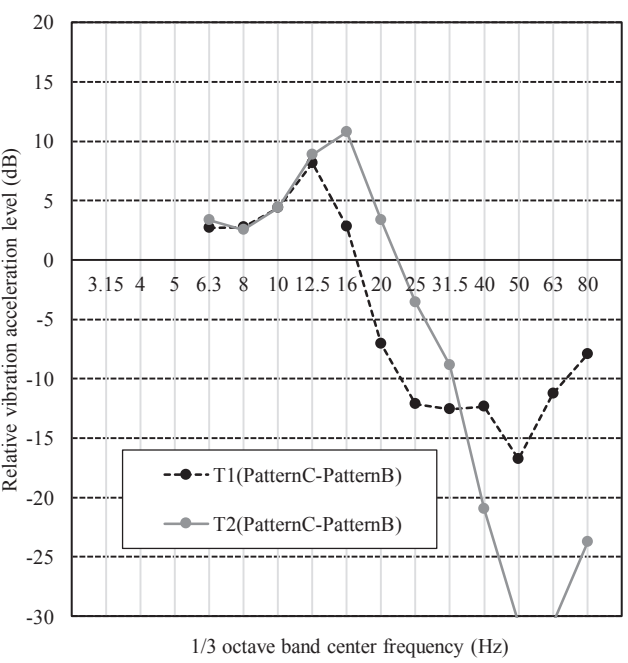

図 7 パターンCーパターンB の結果

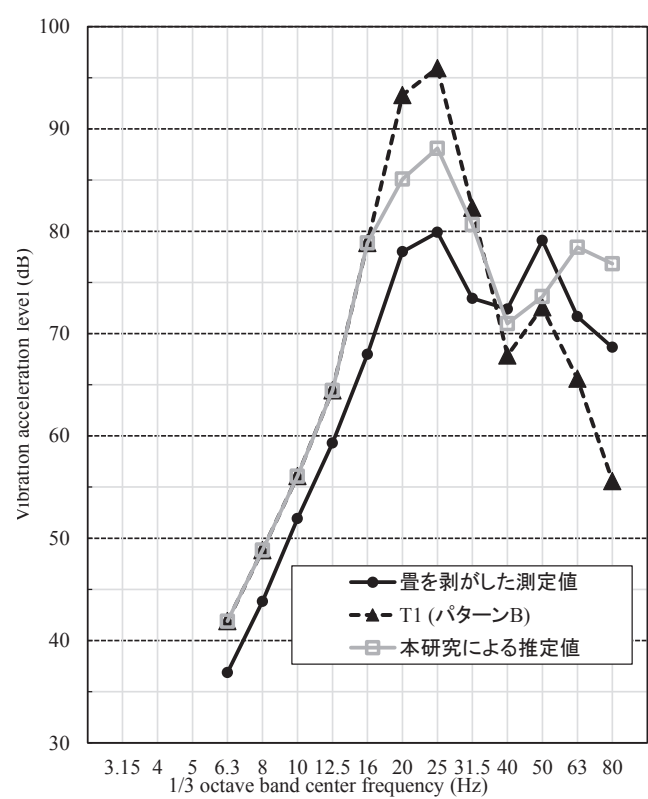

図 9 T1 の推定值と測定值 
本特性は, 図 6 のコンクリートス

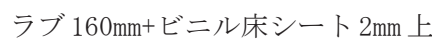
の結果を用いた。

次に，4.1 で示した「測定及び 推定方法」により，(1)(2)の測定を 行い, (3)の結果を図 11 に示す。図 11 を見ると, T1, T2 共に, 図 6 と同様の $16 \mathrm{~Hz}$ 帯域が共振周波数 であることが確認できる。 $\mathrm{f} / \mathrm{fn}=\sqrt{2}$ より高い周波数帯域は, $25 \mathrm{~Hz}$ 帯域以上となる。

4.1 の (4), (5)の結果について, 図 12, 図 13 に 1 1, T2 の推定した 結果を，畳を剥がした実測值と併 せて示す。T2の建材畕の結果であ る図 13 を見ると, $12.5 \mathrm{~Hz}$ 帯域で は $9 \mathrm{~dB}$ と差が大きいが，それ以外 の帯域では最大 $5 \mathrm{~dB}$ とある程度の 推定が可能であることがわかった。 また, T2 をパターン B でそのまま 測定すると, $50 \mathrm{~Hz}$ 帯域の共振によ り，9dB 増幅することがわかった。

一方, T1の本畳の結果である図 12 を見ると, T1 をパターン B で測 定するよりは，畳を剥がした測定 值に近い值となるが, $50 \mathrm{~Hz}$ 帯域で は $8 \mathrm{~dB}$ と差が大きい。

ここで，図11のT1，T2 を見る と, 共振の程度が図 6 の防振ゴム 単体の結果に比べて $3 \mathrm{~dB}$ 以上 $(5$ 〜 $7 \mathrm{~dB})$ 小さくなっている。そこで, 4. と同様に, 文献 ${ }^{7)}$ の木造床上 の場合に適用した推定方法 2(4.1 の(4)で全周波数帯域を補正する) で，T1，T2 について再度推定した 結果を図 14, 図 15 に示す。

T2 の建材畳の結果である図 15 を見ると,低域の差も小さくなり， 最大 $5 \mathrm{~dB}$ とある程度の推定が可能 であることがわかった。

一方, T1 の本畺の結果である図 14 を見ると, 図 12 に比べて低域 についても補正されているため, $20 \mathrm{~Hz}$ 以下については最大 $3 \mathrm{~dB}$ とか なり測定值に近い值が得られた。しかし， $50 \mathrm{~Hz}$ 帯域では $8 \mathrm{~dB}$ と差が 大きい。

\section{6. まとめ}

本報では，これまでカーペット床について検討してきた，設置共 振を防ぎ，床構造の振動加速度レベルを推定する方法について，鉛 直振動を対象に, $55 \mathrm{~mm}$ と厚さのある畳にも適用できるかについて実 験的検討を行った。その結果，以下の内容が明らかになった。
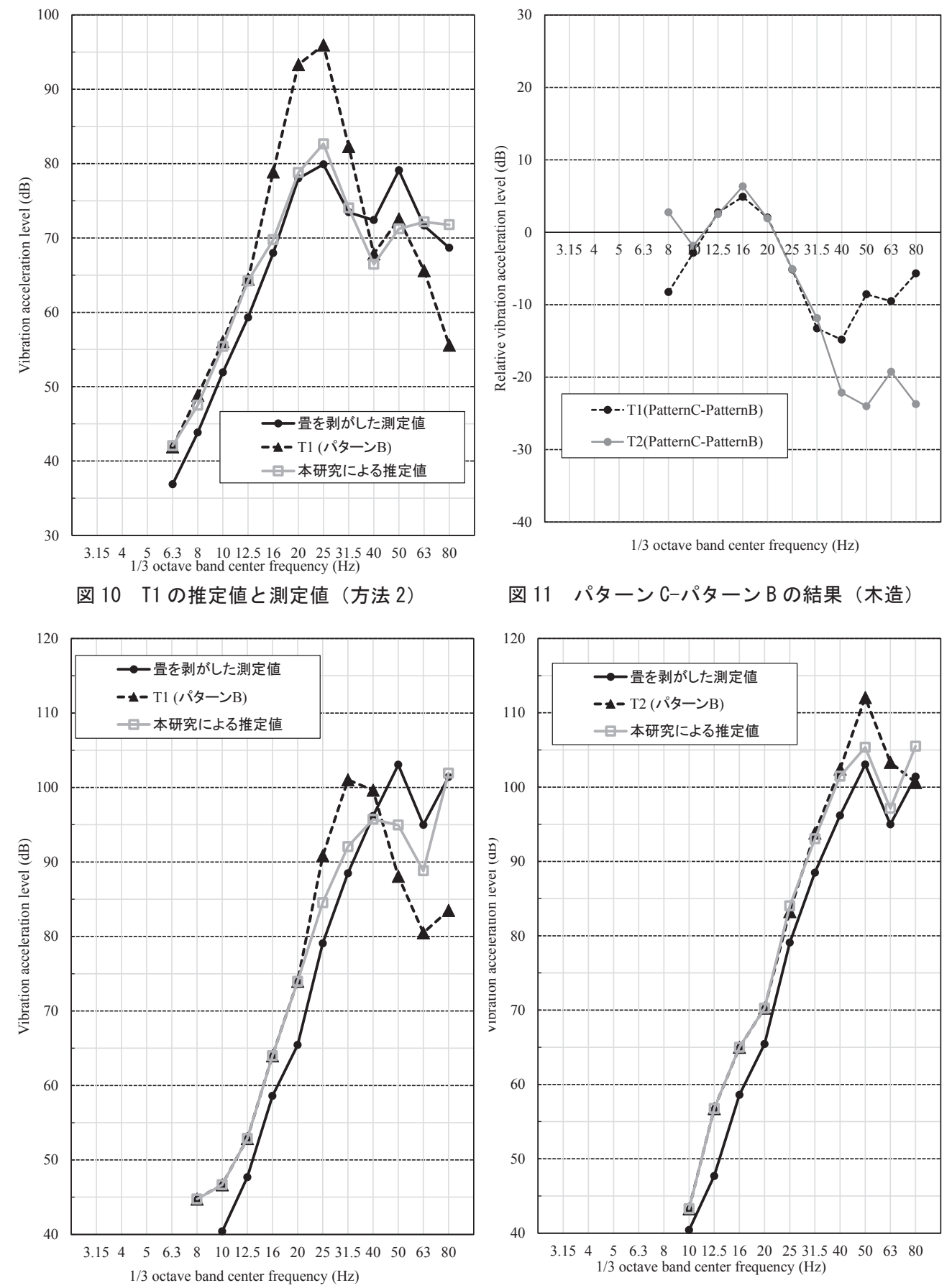

図 12 T1 の推定值と測定值（木造）
図 11 パターンC-パターンB の結果（木造）

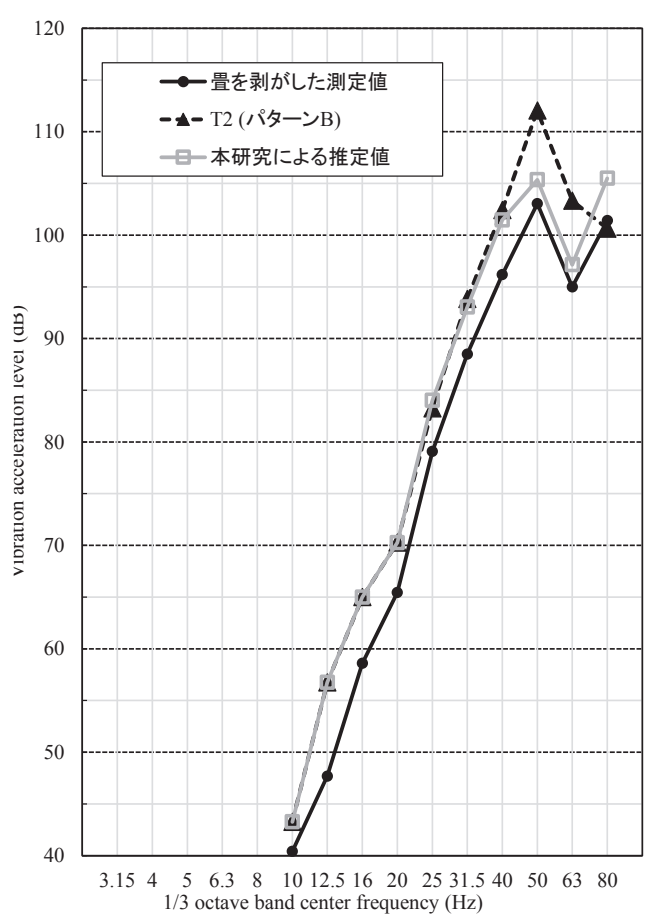

図 13 T2 の推定値と測定値（木造）

(1)コンクリートスラブ上に, 建材畳を施工した場合には, 本研究の 提案方法でカーペット床と同様に精度よく, 設置共振をキャンセ ルした結果を推定することができる。なお, 今回の結果では, $10 \mathrm{~Hz}$ 以上の帯域で推定值は, 畳を剥がした測定值と最大 $2 \mathrm{~dB}$ の差であ った。

(2)コンクリートスラブ又は木造床上に, 本畳を施工した場合には, 推定方法 2 で行えば, $50 \mathrm{~Hz}$ 以外では最大 $6 \mathrm{~dB}$ の差であった。 $50 \mathrm{~Hz}$ 帯域は, コンクリートスラブ, 木造床上共に, $8 \mathrm{~dB}$ の差であった。 (3)木造床上に, 建材畳を施工した場合には, 推定方法 2 で行えば, 最大 $5 \mathrm{~dB}$ の差であった。 
以上のように, 本報の結果から， コンクリートスラブ上に，一般的 によく使用されている建材畳を施 工した場合には, 設置共振をキャ ンセルしてコンクリートスラブの 振動加速度が, 精度よく求められ ることが示唆された。また，建材 畳について，木造床上でも，最大 $5 \mathrm{~dB}$ の差はあるものの概称推定方 法の妥当性が示唆された。今後, 木造床の特性を踏まえた提案を行 うことで，実用的な方法が提案で きる可能性が示唆された。

一方，本畳については，50Hz 帯 域を中心に，推定値と畳を剥がし た測定值との乘離が大きい。今後, この点を踏まえ，更なる検討を行 っていく予定である。

\section{参考文献}

1）冨田隆太：環境振動の測定方法，騒 音制御, Vol.35, No.2, pp. 166-170, 2011.4

2) Tomita R., Goto Y.: Proposal for Environmental Vibration Measurement Method on Carpet using Vibration Control Rubber, Journal of Environmental Engineering (Transactions of AIJ), Vol.84, No.761, pp. 635-641, 2019.7 (in Japanese)

冨田隆太, 後藤佑太：防振ゴムを利用したカーペット上での環境振動測定 方法の提案, 日本建築学会環境系論文集, 84 巻, 761 号, pp.635-641, 2019.7

3) Tomita R., Goto Y.: Examination of Environmental Vibration Measurement using Vibration Control Rubber for Horizontal Vibration on Carpet, Journal of Environmental Engineering (Transactions of AIJ), Vol.85, No.769, pp. 205-213, 2020.3 (in Japanese)

冨田隆太, 後藤佑太, 足立大：カーペット上での水平振動に関する防振ゴ ムを利用した環境振動測定方法の検討, 日本建築学会環境系論文集, 85 巻, 769 号, pp.205-213, 2020.3

4）日本建築学会編：環境振動・固体音の測定技術マニュアル，オーム社, 1999.3

5) Yokoshima,S., Tomita R., Kotani T., Izumi Y.: Issue and Current Status of Measurement, Analysis, and Evaluation of Environmental Vibrations in Buildings - Results Obtained by a Questionnaire Survey of Measurement Experiences-, AIJ Journal of Technology and Design, Vol.24, No.57, pp.697-702, 2018.6 (in Japanese)

横島潤紀, 冨田隆太, 小谷朋央貴, 伊積康彦: 建築物における環境振動に関 する測定・分析・評価の課題と現状一測定経験者を対象としたアンケート 調查から一, 日本建築学会技術報告集, 24 巻, 第 57 号, pp.697-702, 2018.6 6) 足立大, 小谷朋央貴：環境振動測定における振動ピックアップの設置共振 その 1 正弦波加振の場合, 日本建築学会大会学術講演梗概集, 環境工学I , pp.415-416, 2017.7

7）冨田隆太，後藤佑太：防振ゴムを利用したカーペット床の環境振動測定方 法の検討, 日本音響学会騒音振動研究会資料, N-2019-32, pp.1-8, 2019.6

8）冨田隆太，後藤佑太：防振ゴムを利用した畳上の環境振動測定方法の検討, 日本騒音制御工学会秋季研究発表会講演論文集, pp.203-206, 2019.11

9）冨田隆太，後藤佑太，青木怜依奈：防振ゴムの振動伝達率を利用した畳床 の環境振動測定方法に関する実験的検討, 日本騷音制御工学会春季研究発 表会講演論文集, pp.11-14, 2020.4

10）日本建築学会編：実務的騒音対策指針，第 2 版，技報堂出版, 1997.4

11) JIS A 1418-2 : 2019, 建築物の床衝撃音遮断性能の測定方法一第 2 部：標

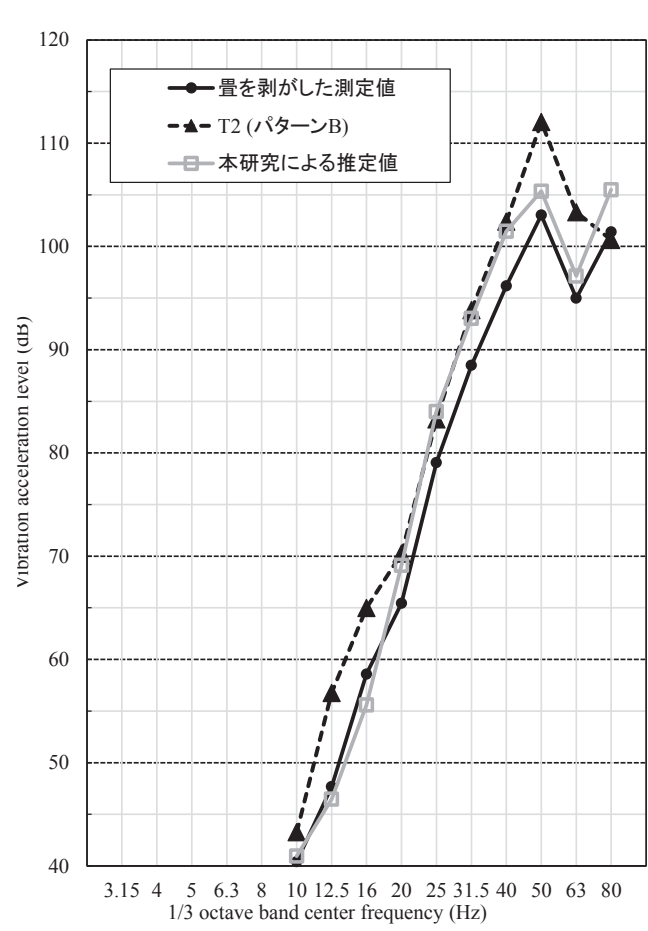

図 15 T2 の推定值と測定値（木造, 方法 2）

準衝撃源による方法

[2020 年 5 月 18 日原稿受理 2020 年 8 月 19 日採用決定］ 